\title{
Growth, Yield and Resistance Responses of Three Cultivars on True Seed Shallots to Twisted Disease with Salicylic Acid Application
}

\author{
Rachmanto Bambang Wijoyo ${ }^{1}$, Endang Sulistyaningsih ${ }^{1 *}$ and Arif Wibowo ${ }^{2}$ \\ ${ }^{1}$ Department of Agronomy, Faculty of Agriculture, Universitas Gadjah Mada, Yogyakarta, Indonesia; \\ ${ }^{2}$ Department of Plant Protection, Faculty of Agriculture, Universitas Gadjah Mada, Yogyakarta, Indonesia
}

${ }^{*}$ Corresponding author: endangsih@ugm.ac.id

\begin{abstract}
Twisted disease is one of the main diseases on shallot caused by Fusarium sp. One method to increase the resistance of shallot cultivars to the twisted disease can be performed by using True Seed Shallot (TSS) combining with a salicylic acid application. TSS is known as free pathogen. The objective of the research was to examine the effects of a salicylic acid application to the growth, yield and resistance responses of TSS on Tuktuk, Sanren and Lokananta cultivars to the twisted disease. The research was arranged in factorial Completely Randomized Design (CRD), consisting of two factors with three replications. The first factor included Tuktuk, Sanren and Lokananta cultivars and the second factor comprised salicylic acid applications (without salicylic acid and inoculation, without salicylic acid with inoculation, immersion treatment of salicylic acid with inoculation, spray treatment with inoculation as well as immersion and spray treatment with inoculation). The results showed that the application of salicylic acid in different treatments had the same effects on the growth, yield and resistance of TSS. An interesting result is found, in which the application of salicylic acid by immersing and spraying could reduce the incidence of twisted disease by $12.5 \%$ in TSS. Therefore, the application of salicylic acid by immersing and spraying can be one of the recommended twisted disease management.
\end{abstract}

Keywords: induced systemic resistance; salicylic acid; true seed shallots

Cite this as: Wijoyo, R. B., Sulistyaningsih, E., \& Wibowo, A. (2020). Growth, Yield and Resistance Responses of Three Cultivars on True Seed Shallots to Twisted Disease with Salicylic Acid Application. Caraka Tani: Journal of Sustainable Agriculture, 35(1), 1-11. doi: http://dx.doi.org/10.20961/carakatani.v35i1.30174

\section{INTRODUCTION}

Shallots (Allium cepa L. Aggregatum group) is one of the important horticultural commodities for Indonesian people. Shallots are often used as a condiment to enhance the flavor on other foods because it contains nutrients and compounds that are classified as non-nutritional substances and enzymes that are useful for improving and maintaining the health of the human body (Minh, 2019). The demand for shallots increases every year and tends to be evenly distributed at any time, while the production of shallots is seasonal (Astuti et al., 2019). The decrease of shallots productivity is caused by the attack of plant-disturbing organisms that make cultivars susceptible to pathogens (Yusidah and Istifadah, 2018). The disease can reduce the quality and quantity of shallot yield. Twisted disease caused by Fusarium acutatum is one of the main diseases of shallot plant that caused significant yield loss (Lestiyani, 2015). During 2003-2005, cumulative infection of twisted disease was noted increasing from 48.1 ha to 268.1 ha (BPS, 2017). Typical symptoms of the disease are yellowing of leaves, twisting on the leaves and drying on roots (Wiyatiningsih, 2011).

Agrochemical firms have been actively influencing farmers to continue using chemical pesticides. The use of chemical pesticides tends to

\footnotetext{
* Received for publication May 18, 2019

Accepted after corrections September 25, 2019
} 
cause serious environmental degradation and poses a threat to human health, hence it may not be sustainable (Kamarulzaman et al., 2012). The application of pesticides is the most frequently used method for disease control. The utilization of synthetic pesticides can cause negative impacts on the environment, whereas, the residue can not be decomposed by organisms except certain microorganisms. Moreover, pesticide residues also accumulate in cells or tissues of organisms (Soemirat and Ariesyadi, 2017). Due to the use of synthetic pesticides, therefore an eco-friendlyalternative is needed (Chang et al., 2016). One of the ways to reduce the detrimental effects of chemical pesticides is to apply salicylic acid as a resistance inducer in plants (Dihazi et al., 2011). Induction of resistance is one of the ways that can be applied to control the disease. Induction causes the physiological conditions to activate the resilience system and stimulate the natural resistance mechanism of the host through the application of external inducers, i.e. biological, chemical and physical agents (Agrios, 2005).

In general, farmers cultivate shallots using bulbs seeds (vegetatively). Using seeds from the same shallot bulb cultivar continuously often decreases the quality of bulbs and yields because the quality of the bulbs is less-guaranteed due to the accumulation of pathogens in bulbs (Shimeles, 2014). One of the efforts to increase the resistance of shallot cultivars to the twisted disease can be performed by using TSS (True Seed Shallot) since TSS is known free of pathogens (Pangestuti and Sulistyaningsih, 2011). The use of TSS is one alternative that can be developed to improve the quality of shallot seeds. PT. East West Seed Indonesia is one of the TSS producers that has introduced Tuktuk, Sanren and Lokananta TSS cultivar seeds. The advantages of growing shallots using seeds include reducing production costs both in the provision of planting material and transportation, being free from tubular infectious pathogens and requiring more efficient handling (Sumarni et al., 2016).

Tuktuk cultivars are superior varieties of shallots that can adapt well in the lowlands with a height of 20-220 meters above sea level and are well-planted in the dry season. Tuktuk yields can reach 20-30 tons $\mathrm{ha}^{-1}$, while conventional bulb seed yields range from 8-12 tons $\mathrm{ha}^{-1}$. This contributes to an increase in the production of 1218 tons ha ${ }^{-1}$ (Buda et al., 2018). Sanren cultivar is a shallot variety that can produce well when planted during the dry and the rainy seasons and has a high production level and medium-size bulbs. This variety is resistant to twisted and anthracnose diseases which often attack during the rainy season (Askari-khorasgani and Pessarakli, 2019). Lokananta cultivar is a shallot variety that is resistant to twisted disease, has a high production and is suitable for planting in the lowlands. The yield of bulbs per hectare is \pm 18.49-24.58 tons ha ${ }^{-1}$ (Saidah et al., 2019).

Moreover, the resistance of shallots to twisted disease can also be increased by inducing the resistance using salicylic acid on TSS through immersion or spray technique (Mandal et al., 2009). Accumulation of salicylic acid in plant tissue is involved to activate a signal of Pathogenesis-Related Proteins (PR-proteins) formation and induce systemic resistance mechanism when pathogen infects plant (Juwanda et al., 2016). In addition, the salicylic acid has an important role as a phytohormone that regulates plant growth, especially the physiological activities such as photosynthesis, ethyleneproducing nitrate metabolism, regulation to abiotic stresses and signal molecules that play a role in the resistance to pathogens (Muthulakshmi and Lingakumar, 2017). The objective of the present study is to examine the effects of salicylic acid application to the growth, yield and resistance responses of TSS on Tuktuk, Sanren and Lokananta cultivars to twisted disease.

\section{MATERIALS AND METHOD}

The research was conducted on FebruaryAugust 2018 in the experimental farm, Control Technology Laboratory and Plant Production Management Laboratory, Faculty of Agriculture, Universitas Gadjah Mada, Yogyakarta. The research was arranged in a factorial Completely Randomized Design (CRD), consisting of two factors with three replications. The first factor included TSS cultivars (Tuktuk, Sanren and Lokananta) and the second comprised the application method of salicylic acid (without salicylic acid and inoculation, without salicylic acid with inoculation, immersion treatment of salicylic acid with inoculation, spray treatment with inoculation as well as immersion and spray treatment with inoculation). The materials consist of TSS of Tuktuk, Sanren and Lokananta cultivars, pure Fusarium acutatum culture collection from Control Technology Laboratory, 
sterile soil, manure, NPK fertilizer 15-15-15, SP36 fertilizer, $\mathrm{KCl}$ fertilizer, NPK fertilizer 15-920, aquades, $\mathrm{FeCl}_{3}$, liquid nitrogen, potato dextrose agar (PDA) medium and peptonepentachloronitrobenzene (PCNB) medium.

The treatment of salicylic acid using immersion treatment was carried out by immersing TSS in a 15 ppm salicylic acid solution for 30 minutes following Khotimah et al. (2017). The spray treatment was performed by spraying $15 \mathrm{ppm}$ salicylic acid solution on the seedlings from the seeds as much as $50 \mathrm{ml}$ per $500 \mathrm{~cm}^{2}$ two days before planting (38 days after seedling) (Krishardianto and Sukma, 2017). The planting medium was sterilized soil prepared by steaming in an autoclave for approximately two hours. Sterilized soil was mixed with manure with a dose of 4 tons ha- ${ }^{-1}$ (Suwandi et al., 2016). The mixture of planting media was put into a tray of $32 \mathrm{~cm} \mathrm{x}$ $45 \mathrm{~cm} \times 16 \mathrm{~cm}$. Fusarium sp. was inoculated in the planting medium by drenching method at one week after the transplantation (WAT). The planting medium was poured with $240 \mathrm{ml}$ per tray conidia suspension with a density of $10^{6}$ conidia $\mathrm{ml}^{-1}$ with distilled water (Cahyaningrum et al., 2017).

In the observation, the incubation period was observed, particularly when the symptoms of the twisted disease first appeared in plants in each treatment combination in units of weeks. Disease incidence was observed by counting the number of plants that showed twisted disease symptoms.

$$
\text { Disease incidence }=\frac{\mathrm{a}}{\mathrm{b}} \times 100 \%
$$

Note:

$\mathrm{a}=$ Total number of plants showing twisted disease symptoms

$b=$ Total number of plant population

The total population of Fusarium in the soil was observed by taking a $3 \mathrm{~g}$ soil sample per treatment diluted with $27 \mathrm{ml}$ of aquabidest and then homogenized with a vortex. The suspension was diluted again by taking $1 \mathrm{ml}$ of suspense dissolved with $9 \mathrm{ml}$ of aquabidest and shaken until homogeneous. Dilution was carried out up to $10^{-3}$. Then, the suspension at $10^{-3}$ dilution was taken as much as $100 \mu \mathrm{l}$ and poured on PCNB media and flattened with L-glass and then incubated for 7-14 days. Colony density was calculated by counting the number of fungal colonies in each petri dish and then putting them into the formula (Sinta, 2018).

$$
\text { Total population of Fusarium in the soil }=\frac{\sum \text { Fusarium colony }}{\text { dilution factor } \mathrm{x} \text { ml suspension }}
$$

Salicylic acid content was observed by using spectrophotometry (Warrier et al., 2013). The first step to do this measurement was making a standard solution using distilled water as the solvent to obtain the standard curve equation. After that, $50 \mathrm{mg}$ of fresh leaves were crushed with liquid nitrogen and added with $1 \mathrm{ml}$ of distilled water. The leaf extract was then centrifuged at a speed of $10,000 \mathrm{~g}$ for 10 minutes to take $100 \mu \mathrm{l}$ supernatant and mixed with $0.1 \%$ ferric chloride solution up to $3 \mathrm{ml}$. The complex formation between $\mathrm{Fe}^{3+}$ ions and salicylic acid was violet. The complex formation was determined by spectrophotometry at A540 $\mathrm{nm}$. The absorbance value was entered into the standard curve equation to obtain endogenous salicylic acid content (Warrier et al., 2013).

The data of the surface area and length of roots, leaf area index (LAI), plant growth rate, total dry weight, harvest index and fresh weight of bulbs were obtained. All the observation data were analyzed using variance analysis with $\alpha 5 \%$ followed by DMRT analysis if there were significant differences between treatments.

\section{RESULTS AND DISCUSSION}

The results showed that there was no interaction between cultivars and salicylic acid application methods to the incubation period, disease incidence, total Fusarium population in the soil, root surface area, root length, LAI, plant growth rate, total dry weight, harvest index and natural dry weight of shallot per clump, but there were interactions between cultivars and salicylic acid application methods to the endogenous salicylic acid content. Shallot plants that were inoculated by Fusarium fungus caused twisted disease in the field. Symptoms on the infected plants showed yellowing and twisting on the leaves (Figure 1). 


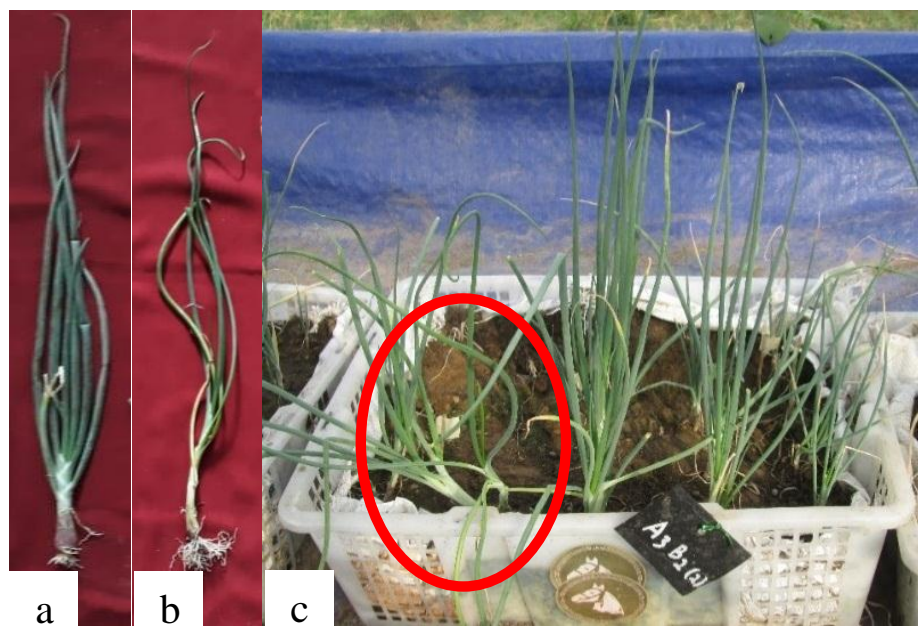

Figure 1. Twisted disease symptoms on shallots, (a) healthy plant, (b) infected plant, (c) yellowing and twisting

The incubation period illustrated the first time of the symptoms of the twisted disease appeared on the shallots. Tuktuk, Sanren and Lokananta cultivars had the same incubation periods (Table 1). Salicylic acid in different application methods did not show any effect on the incubation period. However, the presence of inoculum on the planting medium accelerated the incubation period until five days faster than incubation without fungal inoculation. Tuktuk cultivar had a higher disease incidence than Sanren and Lokananta cultivars. This indicates that Tuktuk cultivars are more susceptible to twisted disease compared to Sanren and Lokananta cultivars. The treatment of salicylic acid by immersing and spraying had reduced the incidence of disease by $12.5 \%$. This result has confirmed that this treatment can significantly reduce disease incidence.

Table 1. The incubation period (the week after inoculation/WAI), disease incidence (\%) at 7 WAT and population of Fusarium in the soil at 16 WAT

\begin{tabular}{|c|c|c|c|}
\hline Treatments & $\begin{array}{l}\text { Incubation } \\
\text { period } \\
\text { (WAI) }\end{array}$ & $\begin{array}{c}\text { Disease } \\
\text { incidence } \\
(\%)\end{array}$ & $\begin{array}{l}\text { Total population of } \\
\text { Fusarium in the } \\
\text { soil (cfu g } \text { - }^{-1} \text { of soil) }\end{array}$ \\
\hline \multicolumn{4}{|l|}{ Cultivars } \\
\hline Tuktuk & $4.13 \mathrm{a}$ & $28.33 \mathrm{a}$ & $9.06 \times 10^{3} \mathrm{~b}$ \\
\hline Sanren & $4.47 \mathrm{a}$ & $22.92 b$ & $17.13 \times 10^{3} \mathrm{a}$ \\
\hline Lokananta & $4.33 \mathrm{a}$ & $20.83 b$ & $8.60 \times 10^{3} \mathrm{~b}$ \\
\hline \multicolumn{4}{|l|}{ Salicylic acid applications } \\
\hline Without salicylic acid, without inoculation & $8.78 \mathrm{p}$ & $5.56 \mathrm{r}$ & $5.44 \times 10^{3} \mathrm{r}$ \\
\hline Without salicylic acid + inoculation & $3.22 \mathrm{q}$ & $34.03 p$ & $11.00 \times 10^{3} \mathrm{pq}$ \\
\hline $\begin{array}{l}\text { Immersion treatment of salicylic acid }+ \\
\text { inoculation }\end{array}$ & $3.11 \mathrm{q}$ & $31.25 \mathrm{pq}$ & $17.33 \times 10^{3} \mathrm{p}$ \\
\hline Spray treatment of salicylic acid + inoculation & $3.44 \mathrm{q}$ & $27.78 \mathrm{pq}$ & $14.56 \times 10^{3} \mathrm{pq}$ \\
\hline $\begin{array}{l}\text { Immersion and spray treatment of salicylic acid }+ \\
\text { inoculation }\end{array}$ & $3.00 \mathrm{q}$ & $21.53 q$ & $9.67 \times 10^{3} \mathrm{q}$ \\
\hline $\mathrm{CV}(\%)$ & 17.64 & 5.29 & 16.77 \\
\hline
\end{tabular}

Note: The numbers followed by the same letters in the same column do not show significant differences based on the DMRT at 5\% confidence level

There were differences in the number of total Fusarium population in soil samples (Table 1). The population of fungus on inoculated soil showed significantly greater results $\left(9.67 \times 10^{3}\right.$ $17.33 \times 10^{3}$ ) compared to those of the population that were not inoculated using Fusarium (5.44 x 
$\left.10^{3}\right)$ in the soil. Fusarium population in the soil demonstrated that they could live in the same conditions in the soil. The twisted disease that had been treated with salicylic acid was different from those without treatment with salicylic acid. Furthermore, the high number of Fusarium at the end of harvest had increased the incidence of plant diseases and shortened the incubation period in shallots. The different application methods of salicylic acid showed no significant results in decreasing Fusarium population in the soil. This indicates that the application of exogenous salicylic acid by immersing the seeds and spraying the nursery does not reduce the Fusarium population in the soil.

The three cultivars of shallots have different responses to the content of endogenous salicylic acid at 10 days after the inoculation (Table 2). Lokananta has significantly higher endogenous salicylic acid content than Sanren and Tuktuk on fungal-inoculated media treatment. However, the same content of endogenous salicylic acid is observed on both Lokananta and Sanren cultivars in immersing and spraying treatments. Abbaspour and Ehsanpour (2016) reported that pathogen inoculation in plants induced plant resistance through the content of endogenous salicylic acid.

Table 2. Endogenous salicylic acid content (ppm) in the leaf at 10 days after inoculation (DAI)

\begin{tabular}{|c|c|c|c|c|c|c|}
\hline \multirow[b]{2}{*}{ Cultivars } & \multicolumn{5}{|c|}{ Application methods } & \multirow[b]{2}{*}{ Average } \\
\hline & $\begin{array}{c}\text { Without } \\
\text { salicylic } \\
\text { acid, without } \\
\text { inoculation }\end{array}$ & $\begin{array}{c}\text { Without } \\
\text { salicylic } \\
\text { acid }+ \\
\text { inoculation }\end{array}$ & $\begin{array}{c}\text { Immersion } \\
\text { treatment } \\
\text { of salicylic } \\
\text { acid }+ \\
\text { inoculation }\end{array}$ & $\begin{array}{c}\text { Spray } \\
\text { treatment of } \\
\text { salicylic } \\
\text { acid }+ \\
\text { inoculation }\end{array}$ & $\begin{array}{l}\text { Immersion } \\
\text { and spray } \\
\text { treatment of } \\
\text { salicylic } \\
\text { acid }+ \\
\text { inoculation }\end{array}$ & \\
\hline Tuktuk & $19.87 \mathrm{de}$ & $27.20 \mathrm{de}$ & $13.20 \mathrm{e}$ & $19.20 \mathrm{de}$ & $32.53 \mathrm{~d}$ & 22.40 \\
\hline Sanren & $18.53 \mathrm{de}$ & $20.53 \mathrm{de}$ & $9.87 \mathrm{e}$ & $15.87 \mathrm{de}$ & $57.87 \mathrm{c}$ & 24.53 \\
\hline Lokananta & 16.20de & $66.53 \mathrm{ab}$ & $77.87 \mathrm{a}$ & 74.53ab & $59.87 \mathrm{bc}$ & 59.00 \\
\hline Average & 18.20 & 38.09 & 33.64 & 36.53 & 50.09 & $(+)$ \\
\hline $\mathrm{CV}(\%)$ & 25.95 & & & & & \\
\hline
\end{tabular}

Note: The numbers followed by the same letters in the same column do not show any significant differences based on the DMRT at 5\% confidence level. The sign $(+)$ shows there is an interaction between factors

Tuktuk cultivars, both with and without fungus inoculation, have the same endogenous salicylic acid. The endogenous salicylic acid content on Tuktuk inoculated with fungus treatment, was not significantly different from that without salicylic acid application. However, salicylic acid application by immersing and spraying increased endogenous salicylic acid content $(59.42 \%)$, significantly higher than the increase in content when using immersing, but not different from then increase when using spraying application. Similar endogenous salicylic acid content was observed on Sanren cultivars, both with inoculation of fungus and salicylic acid by immersing and spraying treatments and without inoculation of fungus and salicylic acid. However, application of salicylic acid by immersing and spraying on the shallots inoculated with fungus appeared to have significantly higher endogenous salicylic acid compared to the plants inoculated with fungus which were treated by immersing or spraying. Lokananta cultivars inoculated with fungus had a significantly higher endogenous salicylic acid compared to plants that were not inoculated with fungus. This cultivar, inoculated with fungus and treated with salicylic acid in different application methods, had the same endogenous salicylic acid with that inoculated with fungus in the planting media without salicylic acid. Salicylic acid treatment by immersing did not have any significant effects on the content of endogenous salicylic acid compared to salicylic acid treatment by spraying or without salicylic acid. However, the content was significantly higher than salicylic acid treatment by immersing and spraying.

Tuktuk cultivar was more susceptible to the twisted disease than both Sanren and Lokananta cultivars. Tuktuk cultivar had lower endogenous salicylic acid content than Lokananta cultivars. Tuktuk cultivars contained endogenous salicylic acid which was the same as the content of endogenous salicylic acid in Sanren cultivars, but it had a different response to the treatment of exogenous salicylic acid. The treatment of 
exogenous salicylic acid in Tuktuk cultivars increased the content of endogenous salicylic acid by $16.38 \%$, whereas the treatment of exogenous salicylic acid in Sanren cultivars increased the content of endogenous salicylic acid to $64.42 \%$. It confirms that Sanren is the most responsive cultivar to the treatment of exogenous salicylic acid. Salicylic acid as an endogenous component of plants is synthesized in response to local and systemic infections produced in uninfected tissue and contributes to systemic expression and systemic resistance induced (Hayat et al., 2013).

Roots are the first part of the plant affected by
Fusarium infection, so observations of root morphology are important (Table 3). Tuktuk, Sanren and Lokananta cultivars had the same length and surface area of roots at 3 and 7 WAT. The treatment of salicylic acid in different application methods gave the same effects on the length and surface area of roots at 3 and 7 WAT. Twisted disease caused by Fusarium sp. is a soilborne pathogen where the initial attack of this pathogen infects the roots or leaves contact directly to the soil surface. Fadhilah et al. (2014) reported that Fusarium-affected plants showed disturbed root growth.

Table 3. The width and length of roots at 3 and 7 WAT

\begin{tabular}{lrrrr}
\multirow{2}{*}{ Treatments } & \multicolumn{2}{c}{$\begin{array}{c}\text { Surface area of roots } \\
\left(\mathrm{cm}^{2}\right)\end{array}$} & \multicolumn{2}{c}{$\begin{array}{c}\text { Length of roots } \\
(\mathrm{cm})\end{array}$} \\
\cline { 2 - 6 } & 3 WAT & 7 WAT & 3 WAT & 7 WAT \\
\hline Cultivars & & & & \\
Tuktuk & $2.84 \mathrm{a}$ & $13.39 \mathrm{a}$ & $6.79 \mathrm{a}$ & $23.23 \mathrm{a}$ \\
Sanren & $3.11 \mathrm{a}$ & $14.41 \mathrm{a}$ & $10.50 \mathrm{a}$ & $23.59 \mathrm{a}$ \\
Lokananta & $3.43 \mathrm{a}$ & $15.53 \mathrm{a}$ & $8.29 \mathrm{a}$ & $18.93 \mathrm{a}$ \\
\hline Salicylic acid applications & & & & \\
Without salicylic acid, without inoculation & $2.94 \mathrm{p}$ & $8.79 \mathrm{p}$ & $7.89 \mathrm{p}$ & $15.82 \mathrm{p}$ \\
Without salicylic acid + inoculation & $3.84 \mathrm{p}$ & $16.35 \mathrm{p}$ & $9.42 \mathrm{p}$ & $22.89 \mathrm{p}$ \\
Immersion treatment of salicylic acid + inoculation & $2.53 \mathrm{p}$ & $19.38 \mathrm{p}$ & $7.30 \mathrm{p}$ & $29.44 \mathrm{p}$ \\
Spray treatment of salicylic acid + inoculation & $2.85 \mathrm{p}$ & $16.02 \mathrm{p}$ & $9.52 \mathrm{p}$ & $23.19 \mathrm{p}$ \\
Immersion and spray treatment of salicylic acid + & $3.49 \mathrm{p}$ & $11.67 \mathrm{p}$ & $8.50 \mathrm{p}$ & $18.24 \mathrm{p}$ \\
inoculation & & & & \\
\hline \multicolumn{1}{c}{$\mathrm{CV}(\%)$} & 23.71 & 25.85 & 28.36 & 28.60 \\
\hline
\end{tabular}

Note: The numbers followed by the same letters in the same column do not show any significant differences based on the DMRT at 5\% confidence level

The LAI is the ratio of the overall leaf area to the land area. The LAI values at 3 and 7 WAT were not significantly different in TSS cultivars and the application method of salicylic acid (Table 4). The application of salicylic acid by immersing, spraying and combination of immersing and spraying on shallots inoculated with fungus showed the LAI values that were not significantly different from the shallots which were not treated with salicylic acid. The shoot also has an important role in the accumulation of dry weight determined by the results of photosynthesis, where the process occurs in the shoot of plants, especially leaves in which the capture of sunlight by the leaves will determine the process of photosynthesis (Zakariyya, 2016).

The growth rate of Lokananta cultivars was $54.66 \%$ and $40.51 \%$ significantly higher than the rates of Tuktuk and Sanren cultivars, respectively (Table 5). The different application methods of salicylic acid gave the effect that was not significantly different from the rate of plant growth. Application of salicylic acid by immersing, spraying and the combination of immersing and spraying which had been inoculated with fungus did not show significant effects on the rate of plant growth compared to the shallots which were not treated with salicylic acid. The growth rate rises by the increase in leaf area of the plant so that much sunlight will be captured and can be used for photosynthesis. The increase in plant growth rate plays an important role in escalating the accumulation of assimilates in parts of the plant which further support the formation of crop yields (Gardner et al., 2008). 
Table 4. LAI at 3 and 7 WAT

\begin{tabular}{|c|c|c|}
\hline \multirow{2}{*}{ Treatments } & \multicolumn{2}{|c|}{ LAI } \\
\hline & $3 \mathrm{WAT}$ & 7 WAT \\
\hline \multicolumn{3}{|l|}{ Cultivars } \\
\hline Tuktuk & $0.81 \mathrm{a}$ & $1.55 \mathrm{a}$ \\
\hline Sanren & $0.98 \mathrm{a}$ & $1.82 \mathrm{a}$ \\
\hline Lokananta & $1.07 \mathrm{a}$ & $2.39 \mathrm{a}$ \\
\hline \multicolumn{3}{|l|}{ Salicylic acid applications } \\
\hline Without salicylic acid, without inoculation & $0.99 p$ & $2.00 \mathrm{p}$ \\
\hline Without salicylic acid + inoculation & $1.07 \mathrm{p}$ & $1.90 \mathrm{p}$ \\
\hline Immersion treatment of salicylic acid + inoculation & $0.88 \mathrm{p}$ & $1.73 \mathrm{p}$ \\
\hline Spray treatment of salicylic acid + inoculation & $0.96 \mathrm{p}$ & $2.33 p$ \\
\hline Immersion and spray treatment of salicylic acid + inoculation & $0.86 \mathrm{p}$ & $1.65 \mathrm{p}$ \\
\hline $\mathrm{CV}(\%)$ & 16.10 & 16.45 \\
\hline
\end{tabular}

Note: The numbers followed by the same letters in the same column do not show any significant differences based on the DMRT at $5 \%$ confidence level

Table 5. Plant growth rate $\left(\mathrm{mg} \mathrm{cm}^{2}\right.$ week $\left.^{-1}\right)$ for the period of 3-7 WAT

\begin{tabular}{lc}
\hline \multicolumn{1}{c}{ Treatments } & Plant growth rate $\left(\mathrm{mg} \mathrm{cm}^{2}\right.$ week $\left.^{-1}\right)$ \\
\hline Cultivars & $1.41 \mathrm{~b}$ \\
Tuktuk & $1.85 \mathrm{~b}$ \\
Sanren & $3.11 \mathrm{a}$ \\
Lokananta & $1.96 \mathrm{p}$ \\
\hline Salicylic acid applications & $1.82 \mathrm{p}$ \\
Without salicylic acid, without inoculation & $1.60 \mathrm{p}$ \\
Without salicylic acid + inoculation & $2.60 \mathrm{p}$ \\
Immersion treatment of salicylic acid + inoculation & $2.65 \mathrm{p}$ \\
Spray treatment of salicylic acid + inoculation & 0.15 \\
Immersion and spray treatment of salicylic acid + inoculation & \multicolumn{2}{c}{ CV $(\%)$} &
\end{tabular}

Note: The numbers followed by the same letters in the same column do not show significant differences based on the DMRT at $5 \%$ confidence level

In general, the application of salicylic acid by immersing, spraying, and immersing and spraying on the three cultivars indicated that accumulation of total dry weight was not different from the total weight of the cultivars that did not receive treatment with salicylic acid (Table 6). The result showed that the total dry weights of both of on three cultivars and in the different salicylic acid applications at 3 WAT were not significantly different. Lokananta cultivar at 7 WAT had a significantly higher total dry weight of plants than Tuktuk and Sanren cultivars. The response of total dry weight accumulation of plants at 7 WAT to the different application methods of salicylic acid was directly proportional to the rate of plant growth. Gardner et al. (2008) reported that total dry weight is influenced by plant growth rate.
The different application methods of salicylic acid have the same effect on the index value of shallot harvest (Table 7). Harvest index shows the proportion of economic dry weight (bulbs) to the total dry weight of shallot. Higher harvest index value indicates that economical dry weight produced by assimilates is high. Lokananta cultivar had a higher total dry weight at 7 WAT than Tuktuk and Sanren. Generally, salicylic acid applications by immersing, spraying, and immersing and spraying on inoculated shallot plants gave the same effect on plants without salicylic acid treatment and without inoculation of fungus on the growing media. This shows that all treatments have the same role in translocating assimilates to bulbs. 
Table 6. Total dry weight (g) at 3 and 7 WAT

\begin{tabular}{lcc}
\hline \multicolumn{1}{c}{ Treatments } & \multicolumn{2}{c}{ Total dry weight $(\mathrm{g})$} \\
\cline { 2 - 3 } Cultivars & $3 \mathrm{WAT}$ & $7 \mathrm{WAT}$ \\
Tuktuk & $0.13 \mathrm{a}$ & $0.54 \mathrm{~b}$ \\
Sanren & $0.15 \mathrm{a}$ & $0.68 \mathrm{~b}$ \\
Lokananta & $0.17 \mathrm{a}$ & $1.07 \mathrm{a}$ \\
\hline Salicylic acid applications & $0.16 \mathrm{p}$ & $0.73 \mathrm{p}$ \\
Without salicylic acid, without inoculation & $0.18 \mathrm{p}$ & $0.70 \mathrm{p}$ \\
Without salicylic acid + inoculation & $0.12 \mathrm{p}$ & $0.58 \mathrm{p}$ \\
Immersion treatment of salicylic acid + inoculation & $0.14 \mathrm{p}$ & $0.89 \mathrm{p}$ \\
Spray treatment of salicylic acid + inoculation & $0.14 \mathrm{p}$ & $0.90 \mathrm{p}$ \\
Immersion and spray treatment of salicylic acid + inoculation & 10.85 & 16.95 \\
\hline \multicolumn{2}{c}{ CV $(\%)$} & $\mathrm{g})$
\end{tabular}

Note: The numbers followed by the same letters in the same column do not show significant differences based on the DMRT at $5 \%$ confidence level

Table 7. Harvest index of three TSS cultivars with different salicylic acid applications

\begin{tabular}{lc}
\hline \multicolumn{1}{c}{ Treatments } & Harvest index \\
\hline Cultivars & \\
Tuktuk & $0.50 \mathrm{a}$ \\
Sanren & $0.42 \mathrm{a}$ \\
Lokananta & $0.48 \mathrm{a}$ \\
\hline Salicylic acid applications & \\
Without salicylic acid, without inoculation & $0.48 \mathrm{p}$ \\
Without salicylic acid + inoculation & $0.43 \mathrm{p}$ \\
Immersion treatment of salicylic acid + inoculation & $0.51 \mathrm{p}$ \\
Spray treatment of salicylic acid + inoculation & $0.48 \mathrm{p}$ \\
Immersion and spray treatment of salicylic acid + inoculation & $0.45 \mathrm{p}$ \\
\hline \multicolumn{2}{c}{ CV $(\%)$} \\
\hline
\end{tabular}

Note: The numbers followed by the same letters in the same column do not show significant differences based on the DMRT at $5 \%$ confidence level

Lokananta cultivar had fresh bulbs weight of $19.44 \%$ which was significantly higher than the fresh bulb weight of Tuktuk and Sanren (Table 8). Fusarium non-inoculated plants on the planting media had the same effects as plants inoculated with Fusarium. Furthermore, salicylic acid treatment in different application methods on the inoculated plants with Fusarium gave the same effects as the plants which were neither treated with salicylic acid nor inoculated.

Fusarium infection on shallot triggers a resistance mechanism through the accumulation of endogenous salicylic acid, especially on the leaves. Salicylic acid application by immersing and spraying can increase the resistance of shallots by decreasing $12.5 \%$ of twisted disease incidence. Successful inducing resistance to the diseases is also influenced by several factors, such as incompatibility between chemicals and plants, appropriate dosage, induction method and period between induction treatment and inoculation (Hayat et al., 2010). Abo-Elyousr et al. (2009) reported that the highest content of endogenous salicylic acid on onion plants is observed at ten days after salicylic acid application and inoculation of $S$. vesicarium. A similar result is also exposed; endogenous salicylic acid content is also found on Tuktuk and Sanren cultivars treated with salicylic acid by immersing and spraying at ten DAI, as well as the salicylic acid on Lokananta cultivar by immersing. However, this application is not significantly different from the plants without inoculation and salicylic acid application on Tuktuk and Lokananta cultivars. 
Table 8 . The natural dry weight of TSS per clump

\begin{tabular}{lc}
\hline \multicolumn{1}{c}{ Treatments } & Natural dry weight of shallots per clump (g) \\
\hline Cultivars & $15.02 \mathrm{~b}$ \\
Tuktuk & $15.01 \mathrm{~b}$ \\
Sanren & $18.62 \mathrm{a}$ \\
Lokananta & $14.59 \mathrm{p}$ \\
Salicylic acid applications & $15.81 \mathrm{p}$ \\
Without salicylic acid, without inoculation & $17.82 \mathrm{p}$ \\
Without salicylic acid + inoculation & $16.78 \mathrm{p}$ \\
Immersion treatment of salicylic acid + inoculation & $16.06 \mathrm{p}$ \\
Spray treatment of salicylic acid + inoculation & \\
Immersion and spray treatment of salicylic acid + & 23.14 \\
\hline inoculation & CV $(\%)$ \\
\hline
\end{tabular}

Note: The numbers followed by the same letters in the same column do not show significant differences based on the DMRT at $5 \%$ confidence level

Induction of resistance in a plant is closely related to the content of salicylic acid as the receptor that will activate the formation of PRProtein (Murphy et al., 2001). In this study, salicylic acid treatment had no significant effects on the incidence of Fusarium in shallots. A similar result was also reported by Khotimah et al. (2017) that exogenous treatment of salicylic acid had no significant effects on the incubation period and the incidence of disease. Disease incidence is more influenced by the genetic structure of plant cultivar than the addition of exogenous salicylic acid. This is in line with the statement of Leino et al. (2018) that each cultivar is affected by different genetic traits. Salicylic acid can support the plant resistance by reducing the percentage of disease incidence, but there does not appear any relation to the plant growth rate, accumulation of total dry weight and fresh weight of bulbs.

\section{CONCLUSIONS}

This study showed that the application of salicylic acid in different application methods gave the same effects on the growth and yield of TSS and the treatment of salicylic acid by immersing and spraying could reduce $12.5 \%$ of the twisted disease incidence in TSS by accumulating its endogenous salicylic acid.

\section{ACKNOWLEDGMENT}

The present study was fully funded by the Australian Center for International Agricultural Research (ACIAR) project HORT 2009-056.

\section{REFERENCES}

Abbaspour, J., \& Ehsanpour, A. (2016). The impact of salicylic acid on some physiological responses of Artemisia aucheri Boiss. under in vitro drought stress. Acta Agriculturae Slovenica, 107(2), 287. https://doi.org/10.147 20/aas.2016.107.2.03

Abo-Elyousr, K. A. M., Hussein, M. A. M., Allam, A. D. A., \& Hassan, M. H. (2009). Salicylic acid induced systemic resistance on onion plants against Stemphylium vesicarium. Archives of Phytopathology and Plant Protection, 42(11), 1042-1050. https://doi.org /10.1080/03235400701621719

Agrios, G. (2005). Plant pathology: Fifth edition. In Plant Pathology: Fifth Edition. https:// doi.org/10.1016/C2009-0-02037-6

Askari-khorasgani, O., \& Pessarakli, M. (2019). Agricultural management and environmental requirements for production of true shallot seeds. Advances in Plants \& Agriculture Research, 9(2), 318-322. https://doi.org/10. 15406/apar.2019.09.00441

Astuti, L. T. W., Daryanto, A., Syaukat, Y., \& Daryanto, H. K. (2019). Technical Efficiency of Shallot Farming in Central Java Province: Stochastic Frontier Modelling. International Journal of Progressive Sciences and Technologies, 13(2), 222-232. Retrieved from http://ijpsat.ijsht-journals.org/index.php/ijpsat /article/view/800

BPS. (2017). Statistik Tanaman Sayuran dan 
Buah-buahan Semusim Indonesia 2017. Retrieved from https://www.bps.go.id/publi cation/2018/10/05/bbd90b867a6ee372e7f51c 43/statistik-tanaman-sayuran-dan-buah---buah an-semusim-indonesia-2017.html

Buda, I., Agung, I., \& Ardhana, I. (2018). Nitrogen Fertilizer Increased Bulb Diameter and Yields of True Seed and Bulb - propagated Shallot Varieties. International Journal of Innovative Research in Science, Engineering and Technologi, 7(1), 80-86. https://doi.org /10.15680/IJIRSET.2018.0701007

Cahyaningrum, H., Prihatiningsih, N., \& Soedarmono, S. (2017). Intensitas dan Luas Serangan Beberapa Isolat Fusarium oxysporum f.sp. zingiberi pada Jahe Gajah. Jurnal Perlindungan Tanaman Indonesia, 21(1), 16-22. https://doi.org/10.22146/jpti.177 43

Chang, P. L., Hsieh, M. M., \& Chiu, T. C. (2016). Recent advances in the determination of pesticides in environmental samples by capillary electrophoresis. International Journal of Environmental Research and Public Health, 13(4), 1-20. https://doi.org/ 10.3390/ijerph13040409

Dihazi, A., Serghini, M. A., Jaiti, F., Daayf, F., Driouich, A., Dihazi, H., \& El Hadrami, I. (2011). Structural and Biochemical Changes in Salicylic-Acid-Treated Date Palm Roots Challenged with Fusarium oxysporum f. sp. albedinis. Journal of Pathogens, 2011, 1-9. https://doi.org/10.4061/2011/280481

Fadhilah, S., Wiyono, S., \& Surahman, M. (2014). Pengembangan Teknik Deteksi Fusarium Patogen Pada Umbi Benih Bawang Merah (Allium ascalonicum) di Laboratorium [Development of Detection Technique for Fusarium Pathogen on Seedling Shallot (Allium ascalonicum) Bulb at Laboratorium]. Hortikultura, 24(2), 171-178. http://dx.doi. org/10.21082/jhort.v24n2.2014.p171-178

Gardner, F. P., Pearce, R. B., \& Mitchell, R. L. (2008). Fisiologi Tanaman Budidaya. In UI Press. Jakarta: UI Press.

Hayat, Q., Hayat, S., Irfan, M., \& Ahmad, A. (2010). Effect of exogenous salicylic acid under changing environment: A review. Environmental and Experimental Botany,
68(1), 14-25. https://doi.org/10.1016/j.envex pbot.2009.08.005

Hayat, S., Ahmad, A., \& Alyemeni, M. N. (2013). Salicylic acid. Plant growth and development. In Reactions Weekly. https://doi.org/10.2165 /00128415-201013250-00111

Juwanda, M., Khotimah, K., \& dan Amin, M. (2016). Peningkatan Ketahanan Bawang Merah Terhadap Penyakit Layu Fusarium Melalui Induksi Ketahanan Dengan Asam Salisilat Secara Invitro. Agrin, 20(1), 15-28. Retrieved from http://lib.ui.ac.id/file?file= digital/2017-5/20451161-310-528-1-SM.pdf

Kamarulzaman, N. H., Mazlan, N., Rajendran, S. D., \& Mohayidin, M. G. (2012). Role of biopesticides in developing a sustainable vegetable industry in Malaysia. International Journal of Green Economics, 6(3), 243-259. https://doi.org/10.1504/ijge.2012.050973

Khotimah, K., Sulistyaningsih, E., \& Wibowo, A. (2017). In Vitro Induced Resistance of Fusarium Wilt Disease (Fusarium oxysporum f.sp. cepae) by Salicylic Acid in Shallot CV 'Bima Brebes.' Ilmu Pertanian (Agricultural Science), 2(1), 001-008. https://doi.org/10.22 146/ipas. 12840

Krishardianto, A., \& Sukma, D. (2017). Morphological Characterization and Effects of Treatments Fertilization and Gift Silica (Si) on Genotype Hybrid Cattleya Orchids. Bul. Agrohorti, 5(2), 167-175. https://doi.org/10. 29244/agrob.5.2.167-175

Leino, M. W., Solberg, S., Tunset, H. M., Fogelholm, J., Strese, E. M. K., \& Hagenblad, J. (2018). Patterns of Exchange of Multiplying Onion (Allium cepa L. Aggregatum-Group) in Fennoscandian Home Gardens. Economic Botany, 72(3), 346-356. https://doi.org/10.10 07/s12231-018-9426-2

Lestiyani, A. (2015). Identifikasi, patogenisitas dan variabilitas penyebab penyakit moler pada bawang merah (Universitas Gadjah Mada). Retrieved from http://etd.repository. ugm.ac.id/index.php?mod=penelitian_detail\& $\mathrm{sub}=$ PenelitianDetail\&act $=$ view $\&$ typ $=$ html \& buku_id=81416\&obyek_id=4

Mandal, S., Mallick, N., \& Mitra, A. (2009). Salicylic acid-induced resistance to Fusarium oxysporum f. sp. lycopersici in tomato. Plant 
Physiology and Biochemistry, 47(7), 642-649. https://doi.org/10.1016/j.plaphy.2009.03.001

Minh, N. P. (2019). Technical Factors Affecting To Pickle Shallot (Allium Ascalonicum) Fermentation. J. Pharm. Sci. \& Res, 11(3), 879-881. Retrieved from https://www.jpsr. pharmainfo.in/Documents/Volumes/vol11issu e03/jpsr11031938.pdf

Murphy, A. M., Gilliland, A., Eng Wong, C., West, J., Davinder, D. P., \& Carr, J. P. (2001). Signal transduction in resistance to plant viruses. European Journal of Plant Pathology, 107(1), 121-128. https://doi.org/10.1023/A:10 08732123834

Muthulakshmi, S., \& Lingakumar, K. (2017). Role of salicylic acid (SA) in plants - A review. International Journal of Appl Ied Research, 3(3), 33-37. Retrieved from http:// www.allresearchjournal.com/archives/2017/v ol3issue3/PartA/3-2-94-381.pdf

Pangestuti, R., \& Sulistyaningsih, E. (2011). Potensi Penggunaan True Seed Shallot (TSS) Sebagai Sumber Benih Bawang Merah Di Indonesia. Semiloka Nasional "Dukungan Agro-Inovasi Untuk Pemberdayaan Petani" Kerjasama UNDIP, BPTP Jateng Dan Pemprov Jawa Tengah, (August 2011), 258266. Retrieved from https://www.research gate.net/publication/308120605\%0APOTENS I

Saidah, Muchtar, Syafruddin, \& Pangestuti, R. (2019). Pertumbuhan dan hasil panen dua varietas tanaman bawang merah asal biji di Kabupaten Sigi, Sulawesi Tengah. Pros Sem Nas Masy Biodiv Indon, 5(1), 213-216. https ://doi.org/10.13057/psnmbi/m050212

Shimeles, A. (2014). The performance of true seed shallot lines under different environments of Ethiopia. Journal of Agricultural Sciences, 59(2), 129-139. https://doi.org/10.2298/jas 14 02129s

Sinta, A. (2018). Aplikasi Bahan Organik dan Trichoderma sp. Untuk Menekan Perkembangan Penyakit Moler pada Bawang Merah (Gadjah Mada University). Retrieved from http://etd.repository.ugm.ac.id/index.php ?act=view\&buku_id=165091\&mod=penelitia n_detail\&sub=PenelitianDetail\&typ=html

Soemirat, J., \& Ariesyadi, H. D. (2017). Toksikologi Lingkungan (Vol. 00). Retrieved from http://ugmpress.ugm.ac.id/id/product/lin gkungan/toksikologi-lingkungan

Sumarni, N., Sopha, G. A., \& Gaswanto, R. (2016). Respons Tanaman Bawang Merah Asal Biji True Shallot Seeds terhadap Kerapatan Tanaman pada Musim Hujan. Jurnal Hortikultura, 22(1), 23. https://doi. org/10.21082/jhort.v22n1.2012.p23-28

Suwandi, Sophan, G. A., \& Hermanto, C. (2016). Petunjuk Teknis (Juknis) Proliga Bawang Merah 40 T/Ha Asal TSS (= True Shallot Seed). Balai Penelitian Tanaman Sayuran Puslitbang Hortikultura, Badan Litbang Pertanian. Retrieved from http:// sumbar.litbang.pertanian.go.id/images/pdf/JU KNIS-PROLIGA.pdf

Warrier, R. R., Paul, M., \& Vineetha, M. V. (2013). Estimation of salicylic acid in Eucalyptus leaves using spectrophotometric methods. Genetics and Plant PhysioloGy, 3(12), 90-97. Retrieved from https://www. researchgate.net/publication/279819825_Esti mation_of_salicylic_acid_in_Eucalyptus_leav es_using_spectrophotometric_methods

Wiyatiningsih, S. (2011). Populasi Fusarium oxysporum f.sp. cepae, Intensitas Penyakit Moler, dan Hasil Umbi Bawang Merah di Tiga Daerah Sentra Produksi. Retrieved from http://eprints.upnjatim.ac.id/id/eprint/3249

Yusidah, I., \& Istifadah, N. (2018). The abilities of spent mushroom substrate to suppress basal rot disease (Fusarium oxysporum f.sp cepae) in shallot. International Journal of Bioscien ces, 13(1), 440-448. http://dx.doi.org/10.126 92/ijb/13.1.440-448

Zakariyya, F. (2016). Menimbang indeks luas daun sebagai variabel penting pertumbuhan tanaman kakao. Warta, (3), 8-12. Retrieved from https://docplayer.info/54696186-Menim bang-indeks-luas-daun-sebagai-variabel-penti ng-pertumbuhan-tanaman-kakao-fakhrusy-za kariyya-1.html 